\title{
Arbeidsmarktprognoses Food Valley 2017-2022
}

Citation for published version (APA):

Peeters, T., \& Cörvers, F. (2018). Arbeidsmarktprognoses Food Valley 2017-2022. ROA. ROA Fact Sheets No. 010C https://doi.org/10.26481/umarof.2018010C

Document status and date:

Published: 01/01/2018

DOI:

10.26481/umarof.2018010C

Document Version:

Publisher's PDF, also known as Version of record

\section{Please check the document version of this publication:}

- A submitted manuscript is the version of the article upon submission and before peer-review. There can be important differences between the submitted version and the official published version of record.

People interested in the research are advised to contact the author for the final version of the publication, or visit the DOI to the publisher's website.

- The final author version and the galley proof are versions of the publication after peer review.

- The final published version features the final layout of the paper including the volume, issue and page numbers.

Link to publication

\footnotetext{
General rights rights.

- You may freely distribute the URL identifying the publication in the public portal. please follow below link for the End User Agreement:

www.umlib.nl/taverne-license

Take down policy

If you believe that this document breaches copyright please contact us at:

repository@maastrichtuniversity.nl

providing details and we will investigate your claim.
}

Copyright and moral rights for the publications made accessible in the public portal are retained by the authors and/or other copyright owners and it is a condition of accessing publications that users recognise and abide by the legal requirements associated with these

- Users may download and print one copy of any publication from the public portal for the purpose of private study or research.

- You may not further distribute the material or use it for any profit-making activity or commercial gain

If the publication is distributed under the terms of Article $25 \mathrm{fa}$ of the Dutch Copyright Act, indicated by the "Taverne" license above, 
Maastricht University $\&$ ROA

\section{Arbeidsmarktprognoses Food Valley 2017-2022}

Tim Peeters

Frank Cörvers

\section{ROA Fact Sheet}

ROA-F-2018/10C

Researchcentrum voor Onderwijs en Arbeidsmarkt | ROA Research Centre For Education and the Labour Market / ROA 


\section{Arbeidsmarktprognoses Food Valley 2017-2022}

Inleiding

Als onderdeel van het Project Onderwijs-Arbeidsmarkt (POA) stelt het ROA sinds 2013 tweejaarlijkse regionale arbeidsmarktprognoses op die tegemoet komen aan de toenemende belangstelling voor regionale arbeidsmarktinformatie. Binnen dit kader past ook voorliggende factsheet met arbeidsmarktprognoses voor de arbeidsmarktregio Food Valley. Deze prognoses bestrijken de periode 20172022 en worden weergegeven voor 24 opleidingscategorieën die verdeeld zijn over zes opleidingsniveaus. Waar mogelijk worden de prognoses vergeleken met deze voor Gelderland als geheel, en wordt er een relatie gelegd met zowel de sector- als opleidingsspecialisatie van de werkgelegenheid in de verschillende regio's. De interpretatie van de prognoses gebeurt steeds vanuit het perspectief van schoolverlaters en werkzoekenden.

De prognoses voor de hele provincie Gelderland evenals een leeswijzer kunnen gevonden worden in de factsheet met nummer ROA-F-20I8/Io. Onderstaande kaart geeft aan hoe Gelderland is samengesteld uit de verschillende arbeidsmarktregio's, en de overzichtstabel laat de verschillende gemeenten zien die in Food Valley gelegen zijn. Zie ten slotte Tekstbox I voor definities van de in deze factsheet gebruikte variabelen.

Arbeidsmarktregio's binnen Gelderland

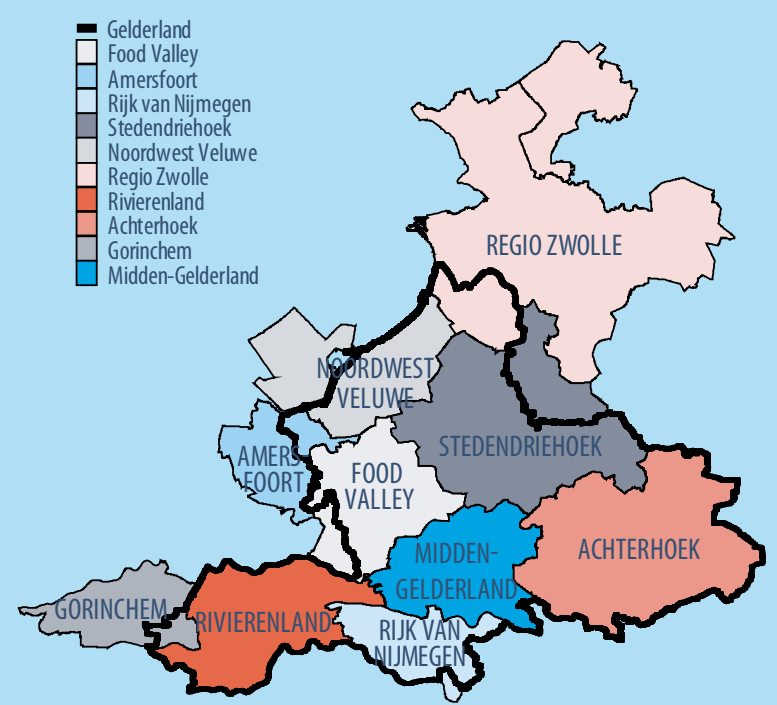

Gemeenten in Food Valley

\begin{tabular}{|l|l|}
\hline Gelderse gemeenten & Niet-Gelderse gemeenten \\
\hline Barneveld & Renswoude \\
\hline Ede & Rhenen \\
\hline Renkum & Veenendaal \\
\hline Scherpenzeel & \\
\hline
\end{tabular}

Scherpenzeel

Wageningen
Prognoses en actuele arbeidsmarktcijfers naar opleidingsniveau

Zoals blijkt uit de prognoses naar opleidingsniveau in Tabel I, wijken de arbeidsmarktperspectieven naar opleidingsniveau voor de arbeidsmarktregio Food Valley doorgaans weinig af van deze voor Gelderland als geheel, en is de geaggregeerde ITA voor beide gelijk aan I,oI. Ondanks dat in Food Valley de uitbreidingsvraag voor alle opleidingsniveaus hoger ligt, geldt dat ook steeds voor de arbeidsmarktinstroom. ${ }^{\mathrm{I}}$

Schoolverlaters van havo/vwo hebben in vergelijking met Gelderland in deze arbeidsmarktregio gemiddeld een matig in plaats van redelijk arbeidsmarktperspectief. Dit is hoofdzakelijk het gevolg van een kleinere vervangingsvraag (gemiddeld $\mathrm{I}, 5 \%$ per jaar) en iets grotere instroom ( $\mathrm{I}, 9 \%$ ). Een hogere uitbreidings- en vervangingsvraag zorgen er dan weer voor dat de vooruitzichten voor hbo-gediplomeerden met een ITA van I,OI iets gunstiger zijn dan in Gelderland $(\mathrm{I}, \mathrm{O} 4)$. Verder hebben basisonderwijs en vmbo niet alleen goede arbeidsmarktperspectieven volgens de ITA, maar kennen schoolverlaters van deze opleidingsniveaus een werkzaamheid die 5\%-punten hoger ligt dan in Gelderland en daarmee de grootste is van alle arbeidsmarktregio's. Bovendien werken ze vaker voltijds. Wo-gediplomeerden werken in Food Valley daarentegen minder vaak voltijds dan in de andere Gelderse arbeidsmarktregio's.

Opvallend is dat de ITA en dus het toekomstig arbeidsmarktperspectief voor basisonderwijs en vmbo $(0,92)$ gunstiger is dan voor wo $(0,99)$. Dit is voornamelijk het gevolg van de grotere vervangingsvraag en kleinere arbeidsmarktinstroom vanuit het basisonderwijs of vmbo (veelal voortijdig schoolverlaters van vmbo, mbo of havo/ vwo). Deze gunstige perspectieven dienen echter met enige voorzichtigheid geïnterpreteerd te worden. Een aanzienlijk deel van de vraag naar personen met basisonderwijs of vmbo als opleidingsachtergrond heeft namelijk betrekking op laagbetaalde en kleine banen. Dit kan afgeleid worden van het relatief lage uurloon (13,7 euro), het lage gemiddeld aantal gewerkte uren per week $(25,5)$ en het hoge aandeel van studenten en scholieren (24\%). Bovendien gaat het vaak om flexibele banen met weinig doorgroeimogelijkheden. Enerzijds blijkt dit uit het lage percentage dat voltijds en vast in dienst is. Anderzijds komt dit ook tot uiting in het slechte loopbaanperspectief. De variabele "typering

I Ruim $20 \%$ van de studenten aan Wageningen University \& Research zijn internationale studenten. Zoals blijkt uit Nuffic (20I7), International degree students in the Netherlands: a regional analysis, Den Haag. Hoewel deze buitenlandse studenten inbegrepen zijn in de instroom, heeft eerder onderzoek aangetoond dat dit geen noemenswaardige effecten heeft op de ITA. Voor meer informatie hierover zie Fouarge, D. \& M. Özer (2014), International mobility of students, It's impact on labour market forecasts and its contribution to the Dutch Economy, ROA-TR-20I5/6, Maastricht. 
loopbaan", die per opleidingsniveau de loongroei tussen ca. 25 en 45 jaar (berekend voor Nederland als geheel) weergeeft in 20I6, is namelijk het minst gunstig voor laagopgeleiden, en het meest gunstig voor havo/vwo. ${ }^{2}$ Deze laatste groep bestaat mogelijk deels uit mensen die geen hogere opleiding hebben afgemaakt omdat ze door hun persoonlijke capaciteiten uitstekende kansen op de arbeidsmarkt hadden.

Verder is van belang dat de groep van laagopgeleiden met basisonderwijs of vmbo heel heterogeen is: niet alleen scholieren, maar ook voortijdig schoolverlaters zonder startkwalificatie (minimaal mbo 2 of havo), schoolverlaters van het speciaal onderwijs en arbeidsgehandicapten. $\mathrm{Bij}$ het aangegeven goede arbeidsmarktperspectief is geen rekening gehouden met de mogelijke sociale, fysieke en cognitieve beperkingen van mensen binnen deze groep.

\section{Sectorspecialisatie}

Uit Figuur I, die de sectorspecialisatie ${ }^{3}$ van Food Valley toont, komt duidelijk naar voren dat deze arbeidsmarktregio een belangrijke specialisatie heeft in de sector informatie en communicatie. Daarmee verschilt ze sterk van de andere arbeidsmarktregio's. Andere sectoren waarin Food Valley een groter werkgelegenheidsaandeel heeft ten opzichte van Nederland zijn groothandel, detailhandel en (in mindere mate) onderwijs. Met betrekking tot de industriesectoren valt op dat hun aandelen in deze arbeidsmarktregio meestal kleiner zijn dan in Nederland en de rest van Gelderland. Ook de aandelen van de zorgsector, energiesector en de sector landbouw, bosbouw en visserij zijn lager dan de Gelderse en Nederlandse aandelen. Anders dan de naam doet vermoeden, is het aandeel werkenden in Food Valley juist kleiner in de voedings- en genotmiddelenindustrie dan het aandeel werkenden in deze sector in de rest van Nederland. Naast deze sector behoren echter ook delen van de groothandel tot de food sector, evenals het speur- en ontwikkelingswerk dat wordt uitgevoerd door Wageningen University \& Research (WUR) en enkele andere onderwijsinstellingen.

\section{Arbeidsmarktperspectieven naar opleidingscategorie}

De prognoses naar opleidingsniveau uit de eerste paragraaf kunnen verder uitgesplitst worden naar opleidingscategorie. Dit is weergegeven in Figuur 2, die per opleidingscategorie binnen het lager en middelbaar (beroeps)onderwijs toont hoe de totale arbeidsvraag en het totale arbeidsaanbod zich naar verwachting

2 De indicator voor loopbaanperspectief wordt berekend aan de hand van het verschil in bruto uurloon van werkenden in de leeftijdsgroep 20-29 jaar en 40-49 jaar. Voor een argumentatie, zie Fouarge, D., Kriechel, B., \& Dohmen, T. (20I4), Occupational sorting of school graduates: The role of economic preferences, Journal of Economic Behavior \& Organization, 106, 335-35I.

3 Gebaseerd op de werkzame beroepsbevolking uit de Enquête Beroepsbevolking (EBB), inclusief zelfstandigen. de komende zes jaar in Food Valley zullen verhouden. Figuur 3 doet hetzelfde voor het hoger onderwijs.

De kleuren bakenen de gebieden af die corresponderen met de vijf eerder besproken ITA-typeringen voor schoolverlaters, gaande van slecht (rood en ITA > I,I5) tot zeer goed (grijs en ITA $\leq 0,85$ ). Deze kunnen geïnterpreteerd worden als kwalitatieve aanduidingen van de verwachte arbeidsmarktperspectieven. Voor de punten op de middelste diagonale lijn zijn verwachte vraag en aanbod aan elkaar gelijk, wat correspondeert met een ITA gelijk aan I. Bijvoorbeeld, voor wo gedrag en maatschappij bedragen het totale aanbod en de totale vraag over zes jaar respectievelijk (afgerond) $28 \%$ en $45 \%$. Deze waarden impliceren een ITA van o,89, zodat wo gedrag en maatschappij zich bevindt in het donkerblauwe gedeelte met het perspectief "goed". ${ }^{4}$ Merk op dat deze ITA een gemiddelde betreft van de opleidingscategorie wo gedrag en maatschappij, en dat er variatie kan bestaan in de arbeidsmarktperspectieven van de onderliggende opleidingstypes.

Behalve voor basisonderwijs/vmbo, mbo 4 techniek en mbo 4 groen, worden voor alle opleidingscategorieën binnen het lager/ middelbaar (beroeps)onderwijs aanbodoverschotten verwacht. De slechtste perspectieven worden daarbij duidelijk voorzien voor mbo $2 / 3$ groen, maar ook mbo 4 economie en mbo $2 / 3$ zorg en welzijn hebben slechte arbeidsmarktvooruitzichten. De situatie is gunstiger in het hoger onderwijs. Daar vallen in eerste instantie de zeer goede perspectieven voor schoolverlaters van wo techniek op, die voornamelijk een gevolg zijn van een bijzonder klein verwacht aanbod. Afgezien van mbo $2 / 3$ techniek zijn de verwachtingen voor schoolverlaters van de andere technische opleidingscategorieën eveneens goed of zeer goed, waarmee de prognoses voor technische opleidingen sterk in lijn liggen met het gemiddelde van Gelderland. Dit suggereert dat de industriële sectoren ook in deze arbeidsmarktregio moeilijkheden kunnen ondervinden bij het invullen van technische vacatures.

Binnen de economische richtingen valt op dat enkel schoolverlaters van wo economie en recht goede arbeidsmarktperspectieven hebben. De vooruitzichten voor mbo $2 / 3$ economie zijn daarentegen matig, en die van hbo economie en mbo 4 economie zelfs slecht. Voor werkgevers in de groot- en detailhandel, sectoren waarin Food Valley een relatief groot werkgelegenheidsaandeel kent, impliceert dit dat ze de komende zes jaar naar verwachting weinig moeilijkheden zullen ondervinden bij het rekruteren van geschikt personeel met een economisch mbo-diploma. Werkgevers in de sector informatie en communicatie, die eerder banen biedt aan gediplomeerde schoolverlaters uit hbo en wo-richtingen, zullen hun economische vacatures op wo-niveau moeilijker in kunnen vullen.

4 De berekening van de ITA is niet louter een deling van aanbod en vraag, aangezien teller en noemer nog dienen vermeerderd te worden met Ioo. 
Relatie arbeidsmarktperspectieven en specialisatie naar opleiding

Figuur 4 toont de relatie tussen de verwachte arbeidsmarktperspectieven (ITA) voor de verschillende opleidingscategorieën over de periode 2017-2022 en de mate waarin Food Valley in deze opleiding "gespecialiseerd" is. Deze laatste variabele is gelijk aan de ratio van het aandeel werkzame personen met een bepaalde opleidingscategorie die in Food Valley wonen ten opzichte van het aandeel van die opleidingscategorie in het Nederlandse totaal. Indien de specialisatiecoëfficiënt voor een opleidingscategorie groter is dan I,Oo, betekent dit dus dat Food Valley in verhouding tot Nederland een groter aandeel van mensen met deze opleiding kent. Bijvoorbeeld, de opleidingsspecialisatiecoëfficiënt van I,24 die hoort bij wo techniek impliceert dat het aandeel van deze opleidingscategorie in Food Valley $24 \%$ groter is dan het aandeel van deze opleidingscategorie in Nederland als geheel. Arbeidsmarkttekorten zijn ernstiger naarmate de specialisatiegraad van de werkgelegenheid voor de betreffende opleidingscategorieën in een regio groter is. Zoals blijkt uit de figuur is er in Food Valley gemiddeld genomen een verschil tussen hogere en lagere opleidingen met betrekking tot de relatie tussen de arbeidsmarktperspectieven (ITA) en de opleidingsspecialisatiecoëfficiënt. De meeste mbo-opleidingen kennen namelijk een ongunstig arbeidsmarktperspectief en zijn tegelijkertijd relatief sterk vertegenwoordigd ten opzichte van Nederland. Dit geldt echter niet voor mbo 4 groen, dat wel goede arbeidsmarktvooruitzichten biedt maar waarvoor betrekkelijk weinig werkgelegenheid voorkomt in deze arbeidsmarktregio.

Binnen de hogere opleidingen valt de uitbijter wo landbouw en natuur op, die zowel een slecht arbeidsmarktperspectief als een werkgelegenheidsaandeel kent dat meer dan drie maal groter is dan het Nederlandse. De zeer grote aanwezigheid van deze opleidingscategorie in combinatie met het feit dat Food Valley slechts een beperkte werkgelegenheid in de sector landbouw, bosbouw en visserij kent (zie Figuur I), geeft aanleiding tot een substantieel overaanbod en een relatief hoge ITA. Verder valt op dat alle technische opleidingscategorieën hier relatief vaker voorkomen dan in Nederland. De hbo-opleidingen zijn verspreid over alle vier de kwadranten, met een ongunstig arbeidsmarktperspectief en lage specialisatie voor hbo taal en cultuur, en een gunstig arbeidsmarktperspectief en wat grotere specialisatie voor hbo onderwijs.

Tekstbox 1 Definities kernbegrippen

\begin{tabular}{|c|c|}
\hline Variabele & Definitie \\
\hline Uitbreidingsvraag & $\begin{array}{l}\text { Vraag naar nieuwe arbeidskrachten die ontstaat door de groei van de werkgelegenheid. Als er sprake is van een werkgelegenheidsdaling, is de uitbreidingsvraag } \\
\text { negatief. }\end{array}$ \\
\hline Vervangingsvraag & $\begin{array}{l}\text { Vervangingsvraag is de vraag naar nieuwe arbeidskrachten die ontstaat door bijvoorbeeld pensionering, (tijdelijke) uittreding vanwege zorgtaken, } \\
\text { arbeidsongeschiktheid, beroepsmobiliteit of doorstroom naar een andere opleiding. }\end{array}$ \\
\hline Arbeidsmarktuitstroom & De som van de vervangingsvraag en de negatieve uitbreidingsvraag. \\
\hline Arbeidsmarktinstroom & $\begin{array}{l}\text { De arbeidsmarktinstroom is het verwachte aanbod van nieuwe arbeidskrachten op de arbeidsmarkt. Deze is gebaseerd op de verwachte uitstroom van } \\
\text { schoolverlaters uit het initiële dag-, deeltijd-, niet-reguliere voltijdonderwijs en de beroepsgerichte volwasseneneducatie. Het weergegeven aanbod in de } \\
\text { figuren } 2 \text { en } 3 \text { is de instroom. Gecorrigeerd voor mobiliteitsstromen tussen arbeidsmarktregio's. }\end{array}$ \\
\hline Baanopeningen & $\begin{array}{l}\text { Baanopeningen zijn de totale vraag naar nieuwkomers op de arbeidsmarkt, zoals deze is bepaald door de werkgelegenheidsgroei (positieve uitbreidingsvraag) } \\
\text { en de vervangingsvraag. In de figuren } 2 \text { en } 3 \text { is dit de vraag naar arbeid. }\end{array}$ \\
\hline ITA & $\begin{array}{l}\text { Indicator Toekomstige Arbeidsmarktperspectief (ITA) van schoolverlaters en werkzoekenden. Deze indicator is gelijk aan een deling van het verwachte aanbod } \\
\text { door de verwachte vraag tot 2022. Naarmate de waarde van de ITA hoger ligt, is er sprake van een slechter arbeidsmarktperspectief. Een waarde tussen 1,01 en } \\
1,05 \text { duidt op een evenwichtssituatie. }\end{array}$ \\
\hline Typering ITA & $\begin{array}{l}\text { Een kwalitatieve beschrijving van de ITA. ITA } \leq 0,85 \text { wordt als "zeer goed" getypeerd, ITA }>0,85 \text { en } \leq 1,00 \text { als "goed", ITA }>1,00 \text { en } \leq 1,05 \text { als "redelijk", ITA }> \\
1,05 \text { en } \leq 1,15 \text { als "matig" en ITA }>1,15 \text { als "slecht". }\end{array}$ \\
\hline Typering loopbaan & $\begin{array}{l}\text { Het bruto uurloon van werkenden in de leeftijdsgroep } 40-49 \text { jaar ten opzichte van het bruto uurloon van werkenden in de leeftijdsgroep } 20-29 \text { jaar. Gemiddelde } \\
\text { cijfers voor Nederland in } 2016 \text {. }\end{array}$ \\
\hline Bruto uurloon & $\begin{array}{l}\text { Gemiddeld bruto uurloon van werknemers in euro's. Enquête Beroepsbevolking (EBB) gekoppeld aan het Sociaal Statistisch Bestand (SSB) van het jaar } 2016 . \\
\text { Gemiddelde cijfers voor Nederland in } 2016 .\end{array}$ \\
\hline Werkenden & Minimaal 1 uur werkzaam per week en in de leeftijd 15-74. Cijfers op basis van de Enquête Beroepsbevolking van het CBS. \\
\hline Werkzaamheid & Het percentage werkzaam is de werkzame beroepsbevolking als percentage van de potentiële beroepsbevolking (iedereen ouder dan 15 en jonger dan 75 jaar). \\
\hline Werkloosheid & $\begin{array}{l}\text { Percentage personen die geen betaald werk hebben, wel recent hebben gezocht en daarvoor direct beschikbaar zijn als percentage van de totale } \\
\text { beroepsbevolking (werkzaam en werkloos). }\end{array}$ \\
\hline Vast werk & Personen met een vast dienstverband. Percentage op basis van werknemers in de werkzame beroepsbevolking. \\
\hline Voltijds & Voltijdarbeid betreft personen die minstens 35 uur per week werkzaam zijn. Percentage op basis van de werkzame beroepsbevolking. \\
\hline Leeftijd & Gemiddelde leeftijd. \\
\hline Uren & Gemiddeld aantal uren werk per week. \\
\hline Student/scholier & Percentage van de werkenden met maatschappelijke positie student/scholier. \\
\hline Sectorspecialisatie & $\begin{array}{l}\text { De verhouding tussen het aandeel van het aantal werkenden in een sector in een bepaalde regio ten opzichte van het aandeel van die sector in Nederland. Een } \\
\text { sectorspecialisatiecoëfficiënt groter dan } 1 \text { impliceert dat het aandeel werkenden in de desbetreffende sector in de regio groter is dan in Nederland als geheel. }\end{array}$ \\
\hline Opleidingsspecialisatie & $\begin{array}{l}\text { De ratio van het aandeel personen met een bepaalde opleidingscategorie die wonen in een bepaalde regio ten opzichte van het aandeel van die } \\
\text { opleidingscategorie in het Nederlandse totaal. Indien de specialisatiecoëfficiënt voor een opleidingscategorie groter is dan 1, betekent dit dat de regio in } \\
\text { verhouding tot Nederland een groter aandeel van mensen met deze opleiding kent. }\end{array}$ \\
\hline
\end{tabular}


Tabel 1

Arbeidsmarktprognoses (2017-2022) en actuele arbeidsmarktcijfers (2015-2016) FoodValley (FOODV) en Gelderland (GLD) naar opleidingsniveau*

\begin{tabular}{|c|c|c|c|c|c|c|c|}
\hline & bo/vmbo & havo/vwo & mbo $2 / 3$ & mbo 4 & hbo & wo & totaal \\
\hline \multicolumn{8}{|l|}{ Prognoses } \\
\hline Uitbreidingsvraag (\%) & 0,9 & 0,8 & 1,0 & 1,0 & 1,0 & 1,1 & 1,0 \\
\hline Vervangingsvraag (\%) & 3,7 & 1,5 & 2,5 & 2,1 & 3,0 & 2,8 & 2,8 \\
\hline Arbeidsmarktinstroom (\%) & 2,1 & 1,9 & 4,7 & 3,7 & 3,8 & 3,5 & 3,3 \\
\hline ITA (F00D V) & 0,92 & 1,07 & 1,08 & 1,07 & 1,01 & 0,99 & 1,01 \\
\hline Typering ITA (FOODV) & goed & matig & matig & matig & redelijk & goed & redelijk \\
\hline ITA (GLD) & 0,93 & 1,04 & 1,07 & 1,08 & 1,04 & 0,99 & 1,01 \\
\hline Typering ITA (GLD) & goed & redelijk & matig & matig & redelijk & goed & redelijk \\
\hline Typering loopbaan (NL)** & slecht & zeer goed & matig & redelijk & redelijk & goed & -- \\
\hline \multicolumn{8}{|l|}{ Actuele indicatoren } \\
\hline Bruto uurloon $(\mathrm{NL})^{* *}$ & 13,7 & 17,3 & 17,7 & 19,2 & 25,1 & 34,7 & -- \\
\hline Werkenden & 26.500 & 10.000 & 20.000 & 21.000 & 26.500 & 16.500 & 121.500 \\
\hline Werkzaamheid (\%) & 53 & 62 & 68 & 79 & 74 & 83 & 67 \\
\hline Werkloosheid (\%) & 5 & 5 & 4 & 5 & 3 & 3 & 4 \\
\hline Vast werk (\%) & 67 & 62 & 88 & 87 & 89 & 91 & 81 \\
\hline Voltijds (\%) & 45 & 31 & 56 & 52 & 53 & 56 & 50 \\
\hline Uren & 27,1 & 23,1 & 32,4 & 31,3 & 32,2 & 33,2 & 30,3 \\
\hline Leeftijd & 36,4 & 32,4 & 41,7 & 39,9 & 41,8 & 45,2 & 40,0 \\
\hline Student/scholier (\%) & 25 & 38 & 1 & 3 & 3 & 0 & 10 \\
\hline
\end{tabular}

"Prognoses als gemiddeld jaarlijks percentage van de werkzame beroepsbevolking in 2016; actuele indicatoren als percentage van de werkzame, totale of potentiële beroepsbevolking 2015-2016 (zie Tekstbox 1), tenzij anders aangegeven

** Lonen voor Nederland in 2016

Figuur 1

Actuele sectorspecialisatie Food Valley ten opzichte van Nederland en Gelderland (2015-2016)

Landbouw, bosbouw en visserij Voedings- en genotmiddelenindustrie

Chemische industrie

Metaalindustrie

Overige industrie Energie

Bouwnijverheid

Detailhandel

Groothandel

Vervoer en opslag

Horeca

Informatie en communicatie

Financiële dienstverlening en onroerend goed

Specialistische zakelijke dienstverlening

Verhuur en overige zakelijke dienstverlening

Openbaar bestuur en overheidsdiensten Onderwijs Zorg

Welzijn

Cultuur sport en recreatie

Overige dienstverlening, huishoudens en extraterritoriale organisaties

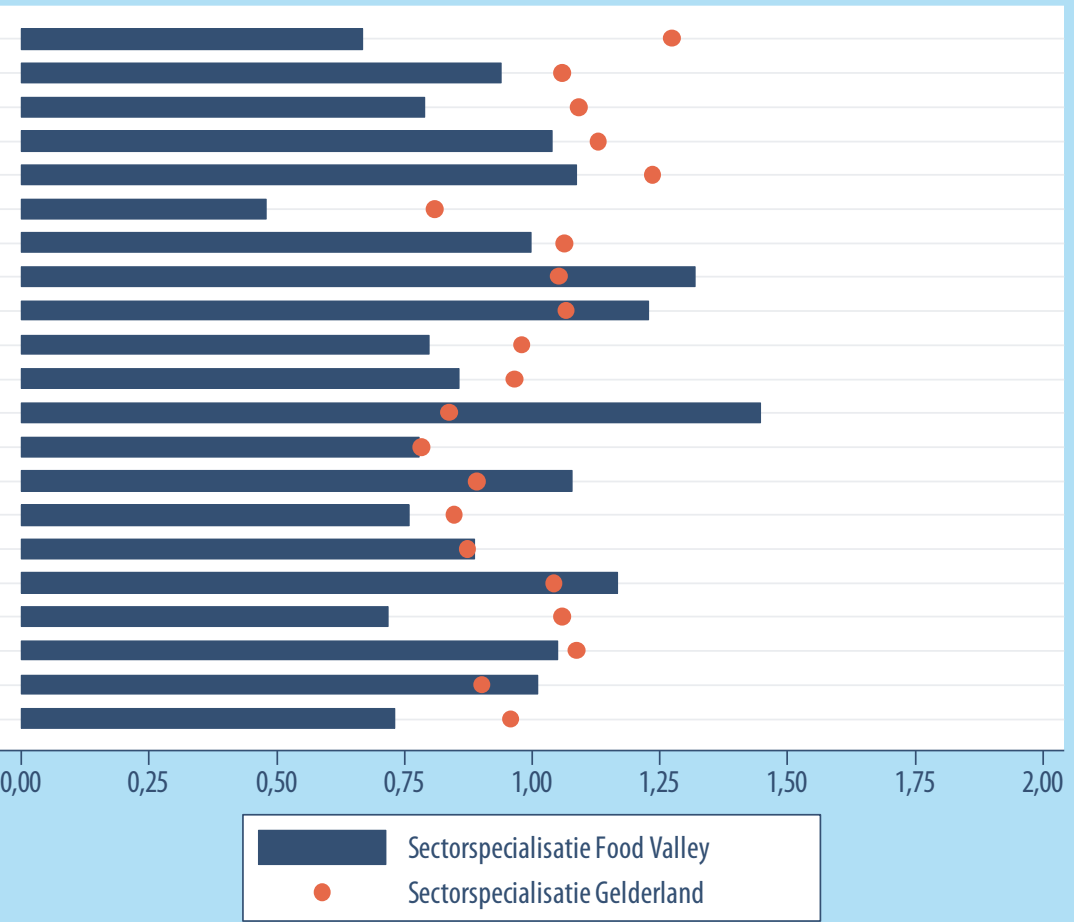


6 Arbeidsmarktprognoses Food Valley 2017-2022

\section{Figuur 2}

Vraag en aanbod voor opleidingscategorieën lager/middelbaar (beroeps)onderwijs, Food Valley (2017-2022)

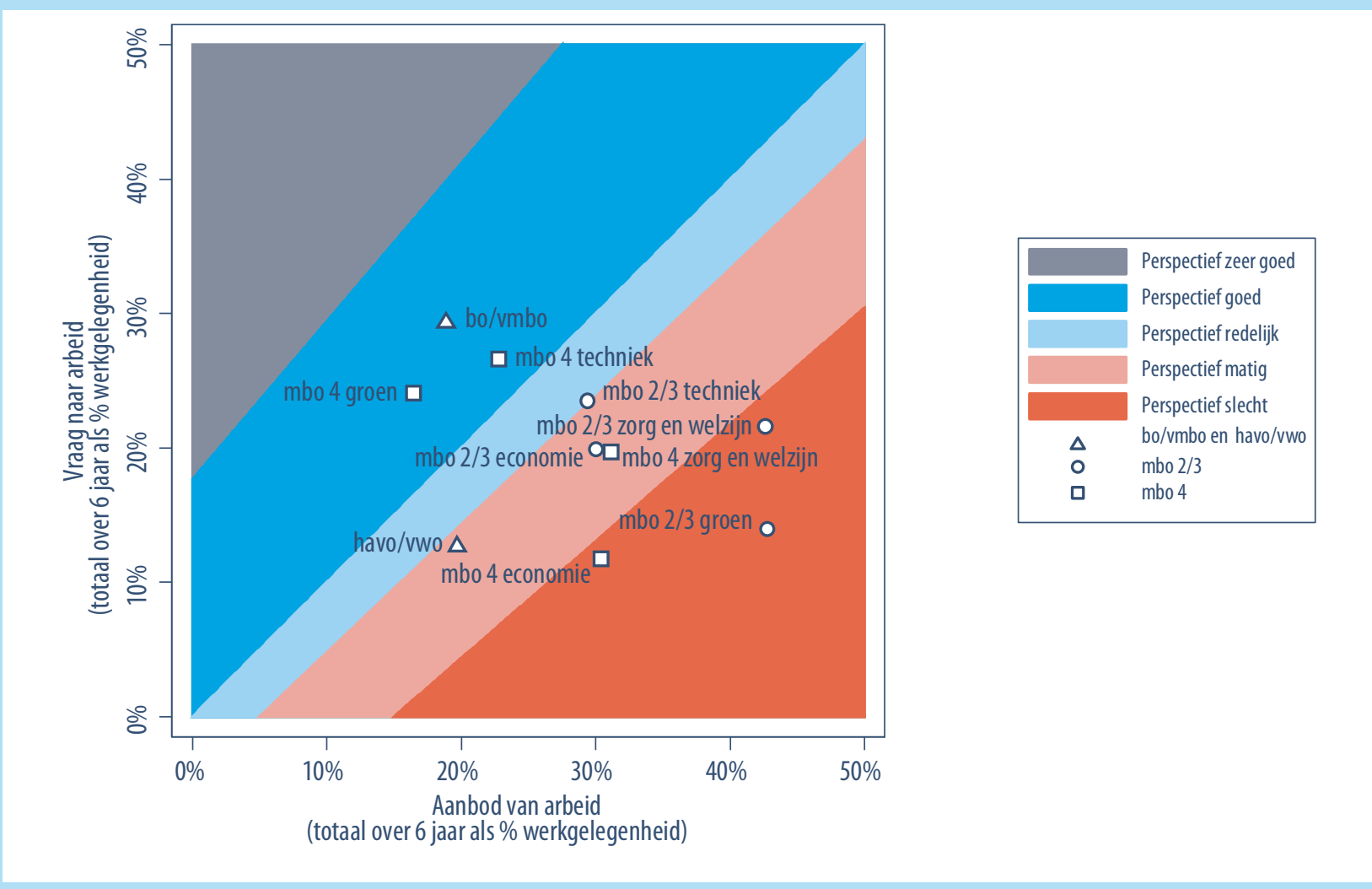

Figuur 3

Vraag en aanbod voor opleidingscategorieën hoger onderwijs, Food Valley (2017-2022)

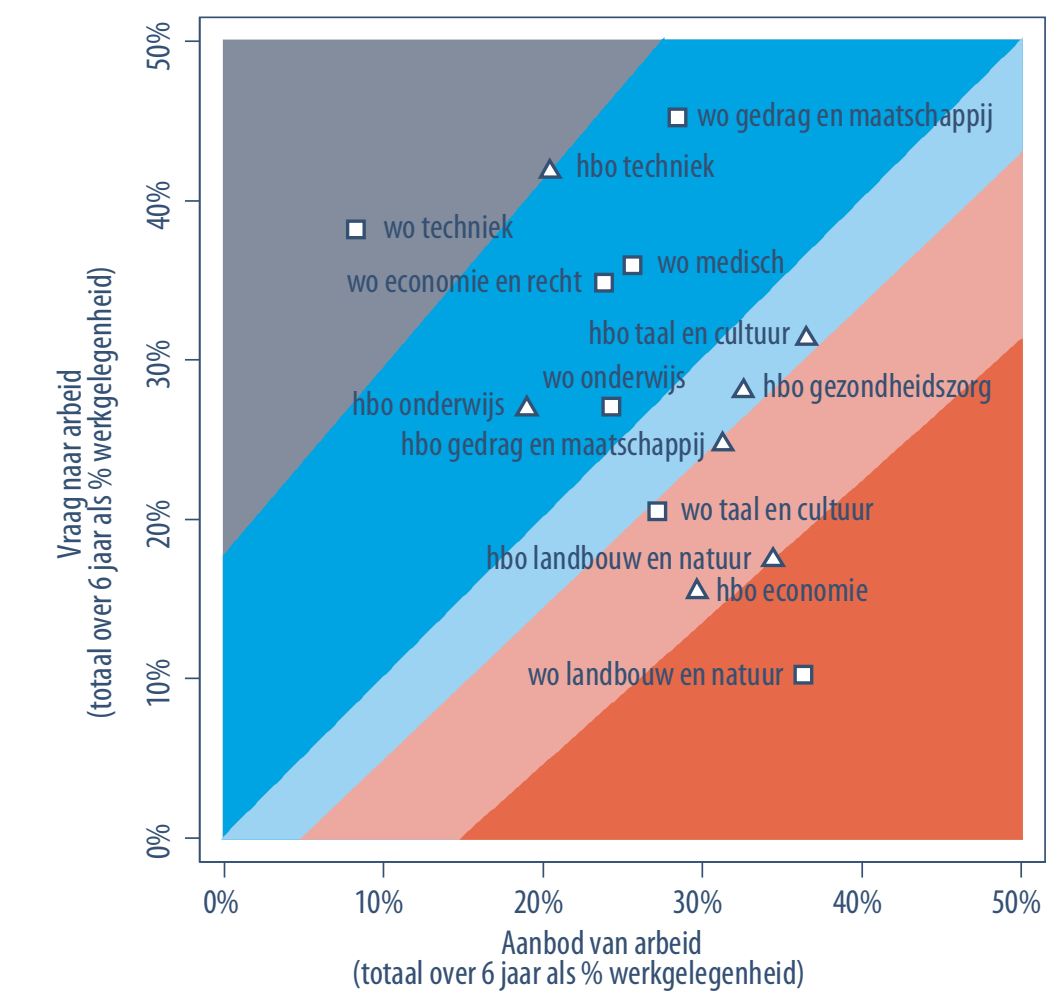

\begin{tabular}{|c|c|}
\hline & Perspectief zeer goed \\
\hline & Perspectief goed \\
& Perspectief redelijk \\
& Perspectief matig \\
& Perspectief slecht \\
\hline$\Delta$ & hbo \\
$\mathbf{D}$ & wo \\
\hline
\end{tabular}


Figuur 4

Arbeidsmarktperspectieven (ITA) versus specialisatie naar opleidingscategorie, Food Valley

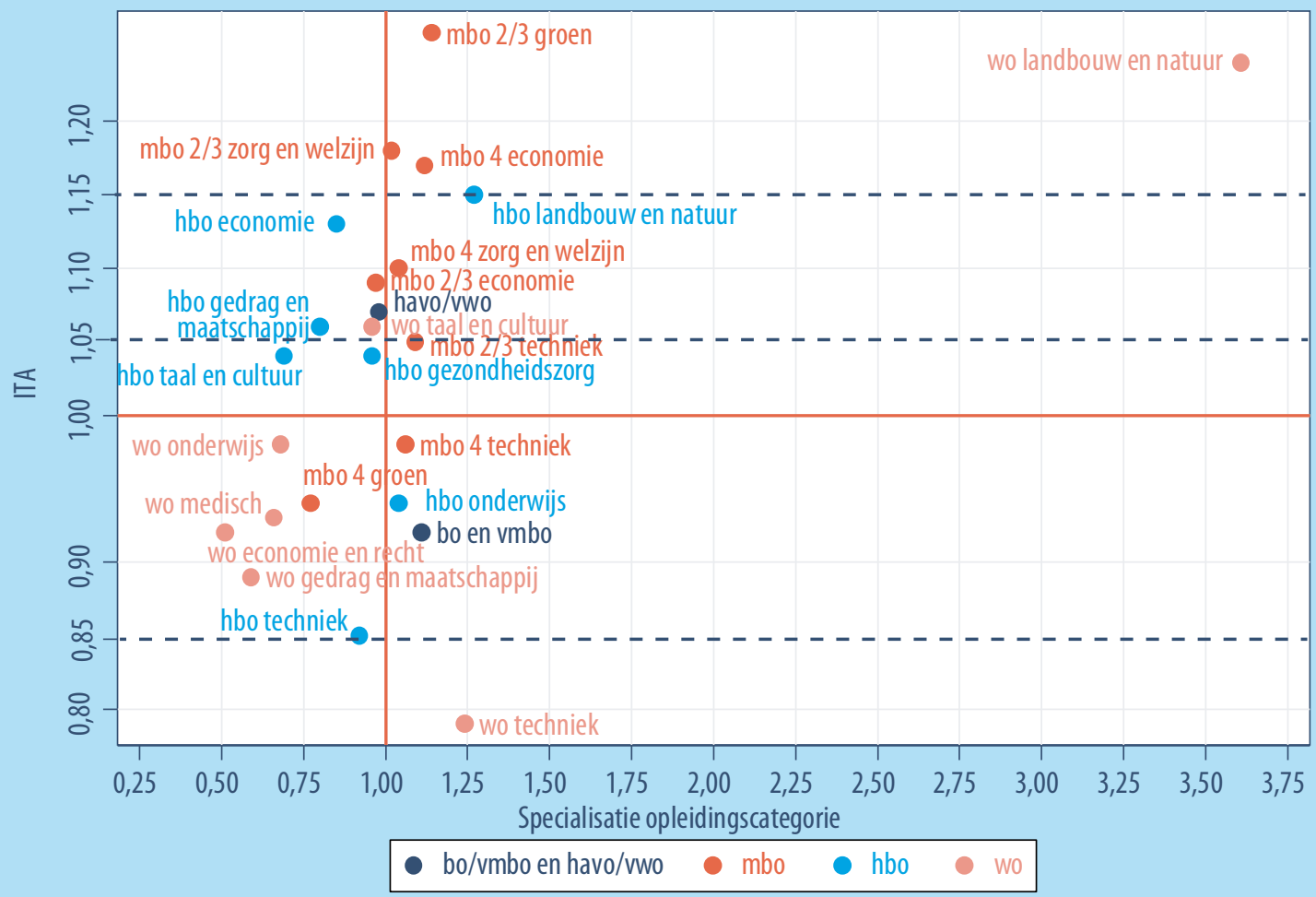




\section{Colofon}

( ) Researchcentrum voor Onderwijs en Arbeidsmarkt Niets uit deze uitgave mag op enige manier worden verveelvoudigd zonder voorafgaande schriftelijke toestemming van de directeur van het ROA.

Researchcentrum voor Onderwijs en Arbeidsmarkt

Maastricht University

School of Business and Economics

secretary-roa-sbe@maastrichtuniversity.nl

www.roa.n

\section{Vormgeving}

ROA secretariaat, Maastricht

juni 2018 